\title{
The Arabic Language: A Latin of Modernity?
}

\section{Tomasz Kamusella}

\author{
University of St Andrews
}

\begin{abstract}
Standard Arabic is directly derived from the language of the Quran. The Arabic language of the holy book of Islam is seen as the prescriptive benchmark of correctness for the use and standardization of Arabic. As such, this standard language is removed from the vernaculars over a millennium years, which Arabic-speakers employ nowadays in everyday life. Furthermore, standard Arabic is used for written purposes but very rarely spoken, which implies that there are no native speakers of this language. As a result, no speech community of standard Arabic exists. Depending on the region or state, Arabs (understood here as Arabic speakers) belong to over 20 different vernacular speech communities centered around Arabic dialects. This feature is unique among the so-called "large languages" of the modern world. However, from a historical perspective, it can be likened to the functioning of Latin as the sole (written) language in Western Europe until the Reformation and in Central Europe until the mid-19th century. After the seventh to ninth century, there was no Latin-speaking community, while in day-to-day life, people who employed Latin for written use spoke vernaculars. Afterward these vernaculars replaced Latin in written use also, so that now each recognized European language corresponds to a speech community. In future, faced with the demands of globalization, the diglossic nature of Arabic may yet yield a ternary polyglossia (triglossia): with the vernacular for everyday life; standard Arabic for formal texts, politics, and religion; and a western language (English, French, or Spanish) for science, business technology, and the perusal of belles-lettres.
\end{abstract}

\footnotetext{
* Tomasz Kamusella, School of History, University of St Andrews, St Katharine's Lodge, The Scores, St Andrews KY16 9BA, Scotland, UK; tdk2@st-andrews.ac.uk

I thank Peter Polak-Springer (Qatar University) and the three anonymous reviewers for their advice and useful suggestions.These corrections and suggestions for improvement are the more important, given the fact that I have no command of Arabic. Hence, necessarily, my reflection is based on secondary literature. This is the usual problem of large-scale comparisons through time and space. A scholar attempting such a feat is always bound to overlook some important details, because she or he will never be able to master all the skills and gather all the information to be able to deal adequately with each single nuance. Hopefully, other researchers interested in the subject may come to succor, correcting errors, and misconceptions that may remain in this text for the sake of either improving such a comparison or falsifying it on the way to working out a better model for analyzing a phenomenon at hand. As mentioned in the article's title, I propose that on the general plane the sociolinguistic situation of today's Arabic-speakers is similar to that of the speakers of vernaculars who employed Latin for written purposes in medieval and early modern (western and central) Europe, usually prior to the Reformation and the Counter-Reformation. A reflection on such a comparison may usefully bring together for the sake of deepened dialog medievalists, sociolinguists, historians, neolatinists, arabists, sociologists, and political scientists, whose research paths would not have crossed otherwise. The alluded interdisciplinary dialog may yet yield a better understanding of both Europe's Latin past and the Arabicphone present of the Middle East and North Africa.
} 


\section{Keywords}

Arabic; diglossia; holy book; Latin, modernity; polyglossia; speech community; standard language; vernaculars

\section{Introduction}

The Arabic language is spoken by over 420 million people. It is an official language in 27 states, from Morocco and Mauritania in the west to Iraq in the east and from Tunisia and Syria in the north to Somalia and the Comoros in the south (Bobkova 2012; List of Countries 2017). 'The original Arabic speakers lived in the Arabian Peninsula. This Semitic language (kindred with Hebrew and Ethiopia's Amharic) coalesced through the ideologically fortified literacy, which was endowed by the fact that the Quran was composed (or "revealed") in Arabic at the beginning of the seventh century. Later, it became the holy book of the Islamic religion, contributing to the dogma that Arabic is the holy language, as spoken only by the religion's true god. In this belief, Arabs and later Muslims of all ethnic origins joined the earlier Abrahamic (monotheistic Judeo-Christian) religions, which had typically defined the written language of their own holy books in this manner (Danecki 2000: 9-21).

\section{From Holy Language to Script to Modern Language}

Jews saw the Hebrew of the Torah (Pentateuch) as god's and the world's original language. The Christians of the Eastern Roman Empire ("Byzantium") accorded the same role to the Greek of the first century in which the New Testament was written. Their western counterparts (later, Catholics) who paid allegiance to the pope in Rome elevated the Roman Empire's official language of Latin to this role, falling back on the early fifth-century official translation of the Bible into this language. Within the Eastern Roman Empire and in its sphere of political and cultural influence, subsequent translations of the Bible (as composed of the Hebrew and Aramaic books of the Old Testament and of the Greek New Testament) led to the emergence of subsequent holy languages, namely, Syriac (East Aramaic, second century) of the Syriac Church, Armenian (Grabar, early fifth century) of the Armenian Church,

\footnotetext{
1 At present (2017), the Arab League has 22 members, namely, Algeria, Bahrain, Comores, Djibouti, Egypt, Iraq, Jordan, Kuwait, Lebanon, Libya, Mauritania, Morocco, Oman, Palestine, Qatar, Saudi Arabia, Somalia, Sudan, Syria, Tunisia, the United Arab Emirates, and Yemen. Arabic is also widely spoken in Eritrea, which has an observer status in this organization. Last but not least, Arabic is a co-official language in Chad, Israel, and Tanzania (Zanzibar). Thus, in today's world there are 22 Arab states and 26 Arabicphone countries. Obviously, the tallies may vary again, if Maltese is treated as a variety of Arabic and the Sahrawi Republic (Western Sahara) is taken into consideration. In such a disposition, the former number would go up to 23 and the latter to 28 (List of Countries 2017; Member 2017).
} 
Georgian (late fifth century) of the Georgian Church, or (Old Church) Slavonic (late ninth century) of the Bulgarian and Rus' Churches.

Importantly, all the aforementioned holy languages became complete with their own specific scripts, not shared by any other holy languages. In this way, by the shape of letters, the faithful of this or that religion or church could identify themselves or others. This symbolical function of scripts was of importance for maintaining clear lines of division among members of various faiths and churches in the situation of overwhelming illiteracy. The narrow stratum who read, wrote, and translated was composed of the top clergymen and scribes from rulers' chanceries. But inscriptions in the holy script were meticulously chiseled on tombs and temple walls for all the faithful to see, remember, recognize, and identify them. Then, when they chanced upon a holy book, they could swiftly decide whether it was of their faith, or of another. Reverence and protection were only due to the former, while the latter had to be avoided or even destroyed.

The importance of religion as expressed through the script of a holy book is underscored by the fact that in the modern age, when numerous "vernaculars" (or un-holy languages) began to be employed for literary pursuits and book production, their users scribbled them in the script of their own holy book. As a result, Latin letters from the Latin translation of the Bible were used for writing English, Spanish, Croatian, German, or Hungarian. In the same way, Jews use the Hebrew script of the original Hebrew language of the Old Testament for writing Ivrit (Modern Hebrew), Yiddish, or Ladino (Spanyol); while Armenians employ the Armenian alphabet in the Armenian translation of the Bible, and they used it for writing Kipchak, Slavic, or Turkish until the turn of the $20^{\text {th }}$ century. The Slavic Orthodox alphabet of Cyrillic - that stems from the Slavonic translation of the Bible - was adopted for writing Belarusian, Bulgarian, Russian, Serbian, or Ukrainian.

The spread of the use of holy scripts for writing other than holy languages (vernaculars) is connected to empires or diasporas. The initial spread of the Latin script took place across the Roman Empire, then Charlemagne's Frankish Empire took over this role, and subsequently the Holy Roman Empire, before the modern colonial empires of Spain, Portugal, Britain, and France, spread the Latin alphabet around the world. The original extension of Cyrillic was connected to the medieval Bulgarian and Serbian empires, although shortly afterward (Kyivan) Rus' introduced this alphabet to vast areas from the White Sea to Black Sea. In the modern times, it was the Russian and Soviet empires, which expanded the use of Cyrillic across northern Eurasia. 
Jews and Armenians migrated from their respective ethnic homelands in Palestine and eastern Anatolia. In diaspora, they adopted languages of their new environments, but infused them with words and phrases of their own liturgical-cum-ethnic languages. Thus, they produced specific Jewish and Armenian ethnolects of these languages, and when they chose to write them down, they did it invariably in their holy scripts of Hebrew and Armenian. Following the Armenian Genocide of 1915 and the Jewish Holocaust, the tradition of literacy in numerous Armenian and Jewish languages or ethnolects was wiped out. Due to these unprecedented calamities, both Armenians and Jews developed their enthnolinguistic national movements modeled on the examples from Central Europe, such as the German nationstate founded in 1871 or the nation-states of Estonians, Hungarians, Poles, or Ukrainians established in the wake of the Great War. The success arrived with the establishment of the Jewish nation-state of Israel in 1948 and of the Armenian nation-state in 1991 after the break up of the Soviet Union. Hence, Ivrit written in the Hebrew script is the sole official and national language of the Jews and Armenian written in Armenian letters is the sole national language of the Armenians, meaning swift marginalization and exclusion of earlier Jewish and Armenian languages and ethnolects.

Currently, for all practical purposes, the holy-cum-secular language of Hebrew (Ivrit) is written with the use of the Hebrew script only, and similarly, the holy-cum-secular language of Armenian is written with the use of the Armenian letters only. This political decision required to construe all the recorded historical forms of Hebrew as a single language from the $10^{\text {th }}$ century $\mathrm{BCE}$ through the $21^{\text {st }}$ century and, similarly, various forms of Armenian in written use from the fifth century through the $21^{\text {st }}$ century are seen as constituting a single language. A similar path, without the experience of empire or diaspora, was followed by other aforementioned holy languages that morphed into present-day (modern and secular) languages and thus upheld the unity of language and script. For example, the use of their respective script has been preserved (almost) exclusively for the language in question, and the various recorded historical forms of these languages have been construed as a single language of long and continuous history.

Therefore, the Syriac script is used for writing the liturgical language of Classical (Biblical) Syriac, in addition to the present-day language of NeoAramaic (Modern Syriac), as used by the faithful of various Syriac Churches in eastern Turkey and Iraq. Similarly, Georgian letters are employed for writing the liturgical language of Georgian (or Old Georgian) and its modern varieties. The Georgian alphabet was employed for writing the Indo-European 
language of Ossetian (spoken in Georgia's break-away autonomous Republic of South Ossetia and Russia's autonomous Republic of South Ossetia-Alania) between 1937 and 1954 in South Ossetia, while Cyrillic was used in North Ossetia. Afterward, Cyrillic was adopted for the entire Ossetian language in both Ossetias. Today, Laz of the very northeastern corner of Turkey speak a Kartvelian language that could be easily defined as "Georgian," but for the fact that they are Muslims. Hence, they wrote their language in Arabic letters until 1928 when Turkey adopted the Latin script. Nowadays, as is the case of Pomaks or Aromanians in Greece, the ethnolinguistic and religious unity of Turkey is emphasized to the marginalization and (at times forced) assimilation of ethnolinguistically non-Turkic groups, such as the Laz.

The unity of script, language, nation, and state is also the case of Greek. The ancient (pre-Christian) written Greek variety or Koine (Common Attic) of the fourth century BCE, the (liturgical) Greek of the New Testament, the Medieval Greek of the East Roman ("Byzantine") Empire (especially after the seventh century when Greek replaced Latin as the official language), and the Modern Greek are construed as a single language, together with rarely committed to the page regional varieties ("dialects") of Cypriot Greek and Pontic. All the diachronic and regional varieties are as different as, or even more so than, English and German or Russian and Polish. The factor that unites all the varieties is the same Greek script and Orthodox Christianity, which in turn is seen as the ideological pillar of the Greek nation and its nation-state of Greece. Hence, the complication of aspirationally federal, bilingual (Greek-Turkish), and bi-confessional (Orthodox and Muslim) Cyprus sits so uneasily with the mainstream of the Greek ethnolinguisticcum-ethnoreligious nationalism.

Obviously, Pontic or Cypriot (Greek) could have developed as separate languages written in the same Greek alphabet shared with the Greek language, but the users of Pontic and Cypriot decided against this possibility and have stuck to the idea of a single and indivisible Greek language. The diaspora of Greek-speakers that arose after the fall of Constantinople in 1453 and the emergence of the Greek nation-state in 1821 yielded some Orthodox communities who spoke or adopted other languages but always wrote them down in Greek letters, for instance, Karamanli (Turkish) in Cappadocia (today's central Turkey), Gagauz (present-day southern Moldova), in addition to Aromanian (Vlach Romance), Arvanitika (Tosk Albanian), or Pomak (Slavic) in present-day Greece. Karamanli was lost in the wake of the 1923 population exchange between Greece and Turkey; Karamanli-speakers, dispersed across Greece, quickly adopted Greek as their language. In the $20^{\text {th }}$ 
century, the Gagauzes' homeland changed hands between Russia, Romania, the Soviet Union, and Moldova, which entailed a series of imposed or ideologized script switches to the Latin alphabet, the Greek script, Cyrillic, and then back to the Latin letters. In Greece itself, the use of the Greek scriptbased Aromanian, Arvanatika, and Pomak is discouraged in the name of the political, ethnolinguistic, scriptural, and religious unity of the Greek nation.

Modern Greek is still a complicated story in its own right. During the Greek Revolution (1821-1831) that produced the Modern Greek nation-state, at the turn of the $19^{\text {th }}$ century, early Greek nationalists under the Western (European) influence had conceived a Katharevousa ("purifying [language]"). It was a compromise variety between Ancient and New Testament Greek on the one hand and Demotic (present-day vernacular Greek) on the other. Katharevousa remained official language in Greece until 1976, when Demotic finally replaced it in the wake of the fall of the military junta (1974), this event paved the way for democracy in this country. These two varieties of Modern Greek, Katharevousa and Demotic, map the main political cleavage in Greek society, namely, between the conservative right and the pro-democratic left. Until today, the Greek Orthodox Church prefers to use Katharevousa for written purposes. However, when it comes to liturgy, the New Testament Greek is the sole acceptable standard language variety. This became obvious when a Demotic translation of the New Testament Greek original of the Gospel of St Matthew was published in an Athens newspaper in 1901. This publishing event led to widespread violent riots, because this translation was seen as both "anti-religious" and "anti-national."

\section{Cesaropapism and Diglossia}

Where does the case of the Arabic language fit the story? The United States linguist Charles A. Ferguson's (1921-1989) main claim to fame is his work on diglossia, which introduced this term to the anglophone academia, and made the phenomenon described by this concept better known among social scientists. Ferguson's article "Diglossia" that appeared in the renowned journal Word in 1959 drew at examples from the Arabic-speaking world. Diglossia denotes a situation wherein all or many members of a speech community or this community's elite employ two or more conspicuously different varieties of a language in clearly delineated separate spheres of (social and political) life. In the case of the Arabic world, these spheres are, namely, everyday life (family, neighborhood, market, and workplace), the religious context (liturgy and prayers), and the official use of language (publications, administration, and official speeches). 
The unity of the holy language of the Quran with its script is underpinned by the strong normative insistence among Islam's faithful that religion and politics are inseparable (Al-Jabiri 2009: 32-33; Lewis 1988: 2). ${ }^{2}$ This doctrine, known as cesaropapism in Western political thought, proposes that the political leader of a polity should also act as a polity's spiritual leader. This was the politico-confessional norm in the East Roman Empire, from where the Arabs borrowed this model and modified for their own needs (cf Kościelniak 2004). In Eastern Christianity, this standard persisted in the Russian Empire until its collapse in 1917 or in Montenegro, where the temporal ruler continued to act as a polity's bishop until 1851. Even the current Constitution of Greece, which provides for the Western-style division of Church and State, nevertheless, in Article 3 states that " $[t]$ he prevailing religion in Greece is that of the Eastern Orthodox Church of Christ." This pronouncement de facto makes Orthodox Christianity into the state-cum-national religion of the Greek nation-state, and the Greek Orthodox Church into the ideological basis of this polity. This ideological link between State and Church is based on the Church's full control of liturgical (New Testament) Greek, as stipulated in Article 3.3: "The text of the Holy Scripture shall be maintained unaltered. Official translation of the text into any other form of language, without prior sanction by the Autocephalous Church of Greece and the Great Church of Christ in Constantinople, is prohibited." Well, the aforementioned 1901 Gospel riots settled this question for now.

On the other hand, in Western Christianity, the separation of Church and State dates back to Charlemagne's renewal of the (Western) Roman Empire in 800. In this year, Pope Leo III crowned him as an Emperor. Henceforth, the sacred was the pope's preserve, while the temporal was the emperor's domain. This consensus was briefly disturbed during the wake of Reformation, when some Protestant rulers became heads of national churches in their respective polities. For instance, today, the British or Swedish monarchs being Heads of State also act as Ecclesiastical Heads of the Church of England and of the (Lutheran) Church of Sweden, respectively. But this Protestant cesaropapism is mitigated on several counts in comparison to its Greek or Eastern Roman counterpart. First, the Protestant monarch is a titular Head of State with no day-to-day power prerogatives, which are executed by the constitutionally elected government. Similarly, the everyday ecclesiastical business is ceded

2 Obviously, this insistence on the inseparability of religion and politics is purely normative in its character. Under the influence of the west in the form of democracy, nationalism or communism, many Arab countries began separating state (politics) from religions since the early $20^{\text {th }}$ century (Lane and Redissi 2009: 145-154). I thank Anonymous Reader 1 for the remark that this issue should be clarified in more detail. 
to the Primate, such as the Archbishop of Canterbury in England and the Archbishop of Uppsala in Sweden. None of the ecclesiasts has any formal control over the norms of the English or Swedish language, whereas nowadays the state religions do not limit the freedom of other religions in Britain and Sweden.

Significantly, during the $16^{\text {th }}$ century, the Protestant Reformation and the Catholic Counter-Reformation resulted, among others, in an ideological consensus that the Bible may be legally translated into vernaculars. In this way, the previously elevated ecclesiastical-cum-secular position of the holy language of Latin was successfully usurped as Western Christianity's sole official (written) language. Numerous vernaculars were shaped into officialcum-national languages based on this model of Latin. Latin persisted as Western Christianity's language of diplomacy and scholarship for a short period, but from the $17^{\text {th }}$ to $19^{\text {th }}$ centuries, French gradually replaced it between Portugal and Russia. What remains from the common Western Christian (Catholic and Protestant) legacy of Latin literacy is the Latin script for writing the post-Latin vernaculars. In Europe, this script is quite a reliable litmus test for ascertaining whether a given (national) speech community belongs or used to belong to the Western Christian community of Catholics and Protestants. However, exceptions do occur as in the case of the Orthodox nation of Romanians, who switched from Cyrillic to the Latin script for writing their Romance(-Slavic) language of Romanian in the mid-1860s. The Moldovans followed suit in 1989, that is, two years before the break up of the Soviet Union, while the Moldovan language continues to be written in Cyrillic in Moldova's breakaway territory of Transnistria under Russia's control. Since the early $21^{\text {st }}$ century, resurgent Russia under Vladimir Putin's rule employs the Cyrillic alphabet and Orthodox Christianity to claim the Slavophone nation-states of Belarus and Ukraine as Russia's rightful sphere of cultural-cum-political influence. Thus, post-Soviet Russia's geopolitical sphere of influence, known as the "near abroad" in the 1990s, morphed into the present-day slogan of the "Russian World" (Russkii Mir).

\section{Arabic Diglossia: Between the Hijrah and the Internet}

Cesaropapism in the Islamic world lasted until the early 1920s. The Sultan ("emperor") of the Ottoman Empire acted as the Caliph ("pope") of all the Muslims. The collapse of the Ottoman Empire and its transformation into the secular Republic of Turkey (1923) constituted the background for the abolishment of the sultanate in 1922, which two years later, in 1924, was followed by the phasing out of the caliphate. Since that moment, in the 
majority of Arabic and culturally Muslim states, rulers have been secular in their character, although most have adopted a plethora of religious attributes in their demeanor. Islam remains the most potent ideology of statehood legitimization and maintenance in the Islamic world. That is why in many Muslim and Arab countries sharia (Quranic religious law) actually constitutes these polities' law. Although the King of Saudi Arabia brandishes the honorific title "the Custodian of the Two Holy Mosques" (thus, announcing his protection over Islam's two holiest cities of Mecca and Medina), he is not a religious leader in the sense of a caliph or the country's most senior cleric. However, since 1972, the kingdom's top ulema (Islamic clergymen) have been members of the Council of Senior Scholars who advise the King on religious and political matters. The only other Islamic country where religion and politics are even more tightly intertwined nowadays is Iran. After the 1979 theocratic revolution, the country's Supreme Leader is one of the very senior Shia clerics or ayatollahs. However, unlike Saudi Arabia, Iran is not an Arabicspeaking country.

Although by and large cesaropapism disappeared from politics and state structures in the Arabicphone polities, the normative idea that politics is religion and both are inseparable remains strong at the level of day-to-day life and political mobilization. "Infidels" (or monotheistic non-Muslims) are often not allowed to enter mosques, or let alone the holy cities of Mecca and Medina, which are strictly off limits to non-Muslims. Blasphemers are regularly prosecuted, imprisoned, and even targeted by self-righteous assassins. Stating publicly that one does not believe in any god(s) is dangerous in extremis, because from an observant Muslim's point of view, atheists known as kafirs ("pagans" or "unbelievers") - are worse than infidels. Although, under sharia, members of other monotheist religions enjoy protection in Islamic states, usually they need to keep a low profile in order to avoid persecution. Furthermore, in the context of the bitter 70 -year-old Jewish-Palestinian conflict over Israel/Palestine, this sharia-based protection of Judaists is frequently observed in breach.

At the level of language and everyday communication, the continuing intertwining of religion and politics in the Arab countries is reflected in persistent diglossia. The Arabic language employed in writing is known in technical linguistic vocabulary under the sobriquet of Modern Standard Arabic. However, users considered this standard language as directly stemming from the holy language of the Quran, which is accorded as the highest normative authority. It is usually (Western) linguists who classify the Classical Arabic of this holy book and Modern Standard Arabic as separate 
varieties or languages. The latter emerged in the course of the employment of the former seventh-century language for the sake of governance, literature, science, and technology in the intervening centuries when numerous political upheavals took place, and the phenomena also subsumed under the general name of modernization, which has unfolded during the past 200 years (Versteegh 2014: 60-84, 221-240).

Between the emergence of Islam and its rapid spread from Arabia to the Atlantic and today's state of Indonesia, this standard language coalesced and acquired features that are different from the Classical Arabic language. The territorial decline of the Turkic ${ }^{3}$-Arabic Ottoman Empire under the pressure of the West and Russia from the late $18^{\text {th }}$ to early $20^{\text {th }}$ century triggered a variety of reform or "modernization" movements across the Arabic and Islamic world. One of these was a program of sponsored and grassroots translations (adaptations) of Western philosophical and scientific works, as well as literature, into Arabic in semi-independent Ottoman Egypt during the long $19^{\text {th }}$ century. These translations published in relatively large runs decisively shaped Modern Standard Arabic into what it is now. First, at the turn of the 1830s, a theory of equivalence between French and Arabic was proposed. At that time, French was seen as the acme of civilization and the "universal and most logic" medium of "modernity" (or of how the political, social, cultural, technological, or economic relations were organized in the west, ensuring its domination over the rest of the world [cf Malik 2017: 56; Mommsen 1987: 38]). It required quite a leap of faith to propose that Arabic could be French's match. But such faith was not in short supply, as proposers of the idea also saw Arabic as the language of god, thus the world's first-ever language conferred on humanity directly from the heavens. From this perspective, French had to be inferior to the holy language of the Quran. Subsequently, between 1854 and 1873, numerous French works were translated into Arabic, shaping it into a modern language, or a member of the narrow circle of the languages of modernity (meaning media of book production, newspapers, technology and full-scale education from elementary school to university). After Egypt became a British protectorate in 1882, the process was yet repeated when numerous books were translated from English (Tageldin 2011).

Standard Arabic became infused with a variety linguistic loans, neologisms and calques from western languages, which obviously do not occur in

3 I use the term "Turkic" rather than "Turkish" in order to describe the ethnolinguistic character of the Ottoman Empire because, apart from the Turkish-speakers in Anatolia and the empire's official administrative Turkic language of Osmanlıca, this vast polity was also inhabited by speakers of some other Turkic vernaculars and languages, for instance, Crimean Tatar, Gagauz, Karamanli, or Türki (or today's Azeri) (cf Danişmend 1935; Jankowski 2010; Zajączkowski 1966 and 1975). 
the Arabic of the Quran. But, today, in its structures and foundational vocabulary, standard Arabic remains a language that, for all practical reasons, has been removed from day-to-day speech in Arabicphone towns and villages for fourteen centuries. This diglossic gulf of difference between vernacular Arabic and the standard language is broader than that between Katharevousa and Demotic in the case of Greek prior to 1976, when the latter replaced the former as the country's sole official language. Despite its Ancient and New Testament Greek core, Katharevousa was infused with some Demotic elements. It is not the case of standard Arabic, in which the normative ideal is to stick to the early seventh-century "purity" of the language of the Quran. If a vernacular element is found in one's writing, it is a sign of the person's low level of education, such that he cannot frame his thoughts in correct Arabic language. Even worse, it is a departure from the linguistic norm of "god's own language," almost a slide into unbelief. This negative branding of perceived "incorrectness" discourages many Arabic-speakers from using standard Arabic for perusal or for writing longer texts for public consumption.

Not only the language of current Arabic-speakers is different from the standard language on the temporal plane, but the number of regional varieties (dialects) of this language also proliferated and differences among them grew conspicuously in the course of the expansion of Arabic within the Islamic Caliphate from the Maghreb to Mesopotamia. As the rule of thumb, the more the two given varieties are distant from each other in the terms of space, the less mutually comprehensible they tend to be. Scholars distinguish about fifty varieties grouped in six conventional clusters, namely, Maghrebi, Egyptian, Sudanese, Peninsular (that is, of the Arab Peninsula), Levantine, and Mesopotamian. Nowadays, in the age of Arabicphone nation-states, this novel political reality has melded or torn asunder earlier regional varieties shaping them into more than twenty state-centered varieties (Behnstedt and Woidich 2005; Versteegh 2014: 192-220). 
The sheer range of these varieties, which could be easily construed as "six families" of twenty odd different languages ${ }^{4}$ is largely invisible to Arabicspeakers themselves and to the outside (non-Arabic-speaking) world. The former continue to disregard this reality on the ground and emphasize the singular nature of the Arabic language as the holy language of the Quran. On the other hand, non-Arabs (or more exactly, westerners) trust Arabs on that and see Arabic through the lens of their own - invariably - vernacular languages of the West that are both written and spoken in official situations and in everyday life. In the modern period, during the times of the Caliphate, the Ottoman Empire provided a political and religious unity for (almost) all the Arabs (Arabic-speaking Muslims). This unity was emphasized by the holy Arabic language and script of the Quran, to whom all paid allegiance from the lowly illiterate peasant to rulers and civil servants (literati). The illiterate peasant masses revered the language and its script as "sacred symbols" without any immediate need to be able to read or write, while the educated elite employed full-blown Arabic literacy for running the vast empire's administration, armies, and court culture.

When this cesaropapal solution of the Ottoman Empire-cum-Caliphate unraveled in the early 1920s, it was gradually replaced with Arab nationalism, steeped in the Arabic language and script, and by the cultural commonality that stems from, and for that matter remains strongly connected to, Islam. Unlike Europe, where a given national movement aspired to establish for

4 The international standard for the registration of all the world's languages, ISO639-3, enumerates 30 distinctive Arabic varieties or languages, each with its own registration code, nowadays popularly used for language recognition in the cyberspace. These varieties include Algerian Saharan Spoken Arabic [aao] (Algeria), Algerian Spoken Arabic [arq] (Algeria), Babalia Creole Arabic [bbz] (Chad), Baharna Spoken Arabic [abv] (Bahrain), Chadian Spoken Arabic [shu] (Chad), Cypriot Spoken Arabic [acy] (Cyprus), Dhofari Spoken Arabic [adf] (Oman), Eastern Egyptian Bedawi Spoken Arabic [avl] (Egypt), Egyptian Spoken Arabic [arz] (Egypt), Gulf Spoken Arabic [afb] (Kuwait), Hadrami Spoken Arabic [ayh] (Yemen), Hijazi Spoken Arabic [acw], Libyan Spoken Arabic [ayl] (Libya), Mesopotamian Spoken Arabic [acm] (Iraq), Moroccan Spoken Arabic [ary] (Morocco), Najdi Spoken Arabic [ars], North Levantine Spoken Arabic [apc] (Syria), North Mesopotamian Spoken Arabic [ayp] (Iraq), Omani Spoken Arabic [acx] (Oman), Sa'idi Spoken Arabic [aec] (Egypt), Sanaani Spoken Arabic [ayn] (Yemen), Shihhi Spoken Arabic [ssh] (United Arab Emirates), South Levantine Spoken Arabic [ajp] (Jordan), Standard Arabic [arb], Sudanese Creole Arabic [pga] (South Sudan), Sudanese Spoken Arabic [apd] (Sudan), Ta’izzi-Adeni Spoken Arabic [acq] (Yemen), Tajiki Spoken Arabic [abh] (Tajikistan), Tunisian Spoken Arabic [aeb] (Tunisia), and Uzbeki Spoken Arabic [auz] (Uzbekistan). All of them are grouped together in the macrolanguage (inclusive) ISO639-3 code [ara] for the Arabic language (Arabic 2017). However, the Ethnologue's linguistic classificatory scheme includes five more Arabic varieties, which were given separate codes, due to the fact that from the ethnic (ethnoreligious) point of view their speakers are not Arabs. In present-day Israel, some Jews speak Judeo-Iraqi Arabic [yhd], Judeo-Trpolitanian Arabic [yud], Judeo-Tunisian Arabic [ajt], and Judeo-Yemeni [jye], while Maltese [mlt] is Malta's official and national language. Speakers of these ethnically non-Arabic varieties typically do not practice diglossia with standard Arabic, but with Hebrew in Israel, and to a degree with English in Malta. Last but not least, recently a code was added for Hassaniyya Arabic [mey] spoken in Mauritania (Subgroups 2017; Update 2000). 
the postulated nation a separate nation-state, Arab nationalism normatively allows for a plethora of separate (regional) nation-states. The idea of uniting all Arabic-speaking areas into a single Arab nation-state was quite potent in the mid- $20^{\text {th }}$ century at the cusp of worldwide decolonization, but never led to a single stable union of any already established (usually postcolonial) Arab nation-states. The Arab language and the religiously defined cultural commonality (the two pillars of Arab nationalism, characterized by a dual ethnolinguistic and ethnoreligious nature) appear to be quite a well-working functional replacement for the defunct Caliphate-cum-Empire as the unifier of the Arabicphone world at the beginning of the $21^{\text {st }}$ century (Choueiri 2005: 48-55, 82-100, 125-165).

To an Arab not educated about the use of standard Arabic, the language is anything but comprehensible. Earlier, for most people, it was sufficient to learn how to mouth the suras of the Quran, without the need to understand the actual meaning of the uttered words. The faithful oral recitation of appropriate verses from the holy book was sufficient. The religious tradition of learning the relatively correct pronunciation of the holy language is practiced among Judaists (Jews). Prayer books in Hebrew language are commonly published with phonetic notation above or below the verses in the holy language. This notation appears in smaller font in the script and spelling of the official language of a given state in which a target Jewish community resides. Hence, in France, such phonetic notation is given in Latin letters in accordance with the French-style spelling. On the other hand, in Russia, the script is Cyrillic, and orthography used for the aforementioned purpose is that of the Russian language. When in synagogue, irrespective of a country and the language in which they received education, the Judaist faithful can "read" aloud the Torah and prayers in this manner, it is adequate for participating in Judaist liturgy and rites, and allows for the appropriate observation of religious holidays. The voice of god as recited by mouthing the sacred book's verses in the holy language of Biblical Hebrew is the only liturgical requirement placed on the faithful. This situation is similar among Muslims in using Arabic for religious purposes.

In the course of modernization, across the entire region of the Abrahamic religions, irrespective of how strong the normative hold of religion may still remain, the holy language of a sacred scripture was replaced by a vernacular either related or unrelated to the holy language. Some cases of such a last ditch of the language of a holy book in favor of a vernacular for everyday use occurred rather late, for instance, in the mid- $20^{\text {th }}$ century in the case of Jews and in the mid-1970s in the case of Greeks. In the late 1960s, the Catholic 
Church also followed the example of its Protestant counterparts and replaced Latin with the faithful's vernaculars (that would be an anathema to Orthodox Christians in Greece or Judaists to abandon liturgy in their holy languages) for liturgy. In this context, the Arabic-speaking core of the Islamic world is the only case where the holy language became a language of modernity to the exclusion of vernaculars. The six official languages of the United Nations are Arabic, Chinese, English, French, Russian, and Spanish, which are all languages of past or current empires. Among them, Arabic is the only holy language of some sacred scriptures. All other languages are vernaculars, meaning that they enjoy extensive speech communities with hundreds of millions of speakers who use them in everyday life. Standard Arabic was spoken in daily life over a millennium ago; nowadays, there is no speech community of Modern Standard Arabic. No one speaks it as their first ("native") language, that is, as a vernacular. Of course, highly educated Arab parents may decide to raise their children speaking standard Arabic alone. But unless the number of these parents is in the thousands and they live together in a same area (ideally, a state), there is no chance for any revival of Arabic as a "living language" of everyday conversation in a neighborhood. In the absence of such a situation, some parents wishing to make standard Arabic as the first language of their children are able to succeed, paradoxically, only if they reside in a non-Arabic-speaking country. Otherwise, the Arabic vernacular spoken in the streets by their children's playmates would have frustrated their goal in no time. On the other hand, almost no parent would risk such an experiment that would isolate their children from their invariably vernacular-speaking kin and kith in the home country. The expat families usually visit their relatives on a regular basis, and their children are in touch with their grandparents and cousins, with the help of skype. This situation reinforces the use of a specific vernacular variety of Arabic in the expat families. Literate Arabs read and write in standard Arabic. They deliver and listen to official speeches and university lectures in the same language. Every day, all and sundry hear standard Arabic steeped in Quranic recitations during prayers in mosque or when radio or television news are broadcast, where the anchor reads aloud the appropriate written texts. The same is true of the internet which is an intensely literate medium (despite the growing numbers of video materials available in Arabic vernaculars [cf Kindt and Kebede 2017]). But among the mass media, cinema, television and radio are the preserve of vernaculars. Almost one-fourth of Arabic speakers (over 90 million) speak the Egyptian Arabic vernacular, which enjoys a unique edge in the Arabicphone world. This edge is additionally sharpened by the fact that most films and television programs in Arabic are produced in Egypt. As a result, the Egyptian variety 
is the vernacular of popular culture across the Arab world. This vernacular is popularly referred to as Masri, meaning "Egyptian." In order to access and enjoy this attractive popular culture, speakers of other Arabic varieties acquire the Egyptian vernacular mostly in the unofficial context of consuming cultural products offered in this vernacular medium (Amin 1996: 109; Haeri 2003).

The huge gap of difference between standard Arabic and the vernaculars, although noticed and acted upon in communication practices of everyday life, does not inspire many to question the established sociolinguistic status quo. The normative hold of the Quran's holy language is so overwhelming and so deeply ingrained that to most proposing that Arabs should start writing in vernacular would be akin to blasphemy (Danecki 2000: 24). Standard Arabic is intimately intertwined with politics and Islam, which makes it impossible to replace this language with a vernacular or rather a multiplicity of vernaculars. Arab nationalism also mitigates this possibility, negatively branding it as the "danger of disunity." Arab nationalists are ready to concede to the political reality of separate ("regional") Arab nation-states, but not to any break up of the "supra-state" Arabic language of the postulated "pan-state" Arab nation (Farah 1987; Suleiman 2003: 131-146). The example of the Maltese language does not convince either. Maltese-speakers have no problems in communicating with Arabs in Libya, because both Maltese and the Libyan vernaculars belong to the Maghrebi group of Arabic vernaculars. However, Maltese in graphic representation is pronouncedly un-Arabic and un-Islamic, because to writing this language, the "infidel script" of Latin letters is used (Brincat 2011).

Depending on a communication situation, numerous English (and some Italian) loanwords and expressions in Maltese are used, which add up to 5-20 per cent of the language's vocabulary. Non-Maltese words are used especially in the intellectual and technical registers of the Maltese language, while everyday circumstances may be discussed without such non-Maltese intrusions (cf Rosner and Joachimsen 2012: 52-53). Arabic vernaculars are similar to Maltese. When an Arab professional (for instance, an engineer or a medical doctor), instead of switching to English or French, discusses a technical issue, he (almost invariably a male) infuses the local vernacular with foreign words, usually drawn from French in Algeria or from English in Qatar. However, this professional would not even dream to write down his words verbatim in

\footnotetext{
5 Anonymous Reader 1 rightly points out that this example is simplistic and some readers could even see it as "abusive." Obviously, there are many female professionals (or women with university-level education) in Arab countries. However, there are disproportionately more male university graduates. At present, in some Gulf states, women graduates from universities slightly outnumber men, but the former tend to be underemployed, while the latter achieve positions of power in army or civil services, despite their relatively poorer education (cf Cadei 2015; Education 2014). However, the brevity of this article and its comparative goal do not allow for presenting a broader range of sociolinguistic situations.
} 
the vernacular. If he finds it difficult to express in a text, an especially knotty point in standard Arabic, he can always resort to writing about it in English or in French. On the other hand, uneducated or poorly educated masses have no need for specialist language to delve into fine questions of technology, management, or science. The local vernacular is sufficient for navigating everyday circumstances. However, due to widespread work emigration to the West, many Arabic vernaculars acquired numerous English or French loanwords. This trend is reinforced by western popular culture increasingly available through radio, satellite television, and the internet.

Foreign western languages offer a level playing field to women for whom standard Arabic oftentimes entails a steep slope to climb, much steeper than it is in the case of men. In the traditionalist view, still prevalent in most Arab countries (that is, Arabicphone countries, where Arabic is the sole or main official language), education is earmarked for boys. Girls are to stay at home and get ready to become obedient housewives, whose main duty is to give birth to and raise children. Furthermore, women tend to be sequestered to their own female-only space at home, while the outside world tends to be the man's preserve. When venturing outdoors, a pious woman must wear a head and face cover, and ideally a male relative should accompany her. In most Arab countries, active participation in modernity is reserved for men, although nowadays, in the wake of the Arab Spring, this traditionalist approach is challenged in some urban areas. A clear index of this gender gap is literacy. Illiteracy remains high for women in the Arab countries, although it dropped significantly from 65 per cent in 1980 to 40 per cent twenty years later. In the case of school-aged women in the age group of 15-24 years, the drop in illiteracy rate was steeper from 45 to 19.5 per cent between 1980 and 2000 (Hammoud 2000: 20). In the most developed and one of the very richest Persian Gulf states, Qatar, the overall illiteracy rate was 18.8 per cent in 2000 , the gap between men and women being less than three percentual points at 16.9 and 19.6 per cent, respectively. The poorer, but with a longer tradition of stable educational policy, Middle Eastern state of Jordan limited illiteracy rate to 10 per cent. Iraq had been heading this way prior to the two decades of intermittent warfare from 1990 to 2011. Now the illiteracy rate skyrocketed to 61 per cent in Iraq or more than that in impoverished Mauritania where 60 per cent of the inhabitants cannot read or write. Undoubtedly, the Syrian civil war which erupted in 2011 further worsened the illiteracy rate which was around 20 per cent in 2010. Apparently, in the most populous Arab state of Egypt, 45 per cent of people were illiterate in 2000 (Literacy 2003: 12). In 2011, the overall illiteracy rate of the Arab states stood at 33 per cent. The situation was only slightly better than in the subSaharan Africa where the illiteracy rate is 41 per cent (Huebler and Lu 2013: 
8). Obviously, the main difficulty is the expectation that Arab children who are only fluent in a spoken (vernacular) Arabic would learn efficiently from textbooks written in the (as yet) unknown to them, ("foreign") language of standard Arabic. Some educators who recognize this difficulty often make matters worse by writing textbooks in ad hoc "simplified" or "modernized" versions of standard Arabic, thus confusing pupils even more (Haeri 2009: 429)

However, it appears that even in an Arab (Arabicphone) state where high rates of formal literacy in standard Arabic are achieved, books in Arabic language are not used more widely. Something is lacking. Perhaps, the gap that exists between standard Arabic and the local vernacular forbids most Arabs with an average command of this "antique-holy-modern" language of standard Arabic from enjoying fiction. Khaled Al Khamissi's 2006 novel Taxi is composed of stories narrated by Cairo taxi drivers. Memorably, it is the first-ever novel written (almost) entirely in the Egyptian vernacular, the speech of the Egyptian capital's common people. It is so because the author lets the taxi drivers speak in their own voices. Dialogs and plays are the preserve of vernaculars in Arabic literature, among others, pushing writers of fiction to mix creatively standard and vernacular Arabic (Mejdell 2006). Resultant "mixed styles" bring to mind the Russian polymath Mikhail Lomonosov's mid- $18^{\text {th }}$-century plan for the development of the Russian language, which was to be composed of three "styles." These styles differed in how they combined official Church Slavonic (or the language of the $9^{\text {th }}-10^{\text {th }}$-century Slavic translation of the Bible) and Moscow's Slavic vernacular. Official and "serious" texts and genres were to employ the "high style" or mostly Church Slavonic. The "low style," or predominantly the vernacular, was to be used for writing plays, Church Slavonic limited to the stage directions. On the other hand, narrative poetry and fiction were to be written in the "middle style" or an equitable mixture of Church Slavonic and the vernacular. At the turn of the $19^{\text {th }}$ century, the historian and writer Nikolai Karamzin limited this tripartite division to the middle style only. Subsequently, in the 1820s and 1830s, Russian romantic poets, led by Alexander Pushkin, thank their highly popular poetry and fiction, which made the middle style into what is now known as the Russian language (Stacy 1974: 16, 25-26).

It appears that nowadays there are only two "styles" of this kind in Arabic, namely "high" (standard Arabic) and "low." The "high style" is used for any written purposes, apart from dialogs and plays which are commonly rendered in the "low style" of vernaculars (cf Miler 2017: 92). ${ }^{6}$ Perhaps, in the wake

\footnotetext{
6 An interesting anthology of texts in Egyptian Arabic from the $15^{\text {th }}$ century through the turn of the $21^{\text {st }}$ century is offered by Doss and Davies (2013). However, writing and publishing in a vernacular became a clear trend only in the $19^{\text {th }}$ century (cf Rosenbaum 2011).
} 
of the Arab Spring, with the widespread use of social media, now a "middle style" is in making (cf Kindt and Kebede 2017; Mejdell 2006; Miler 2017: 108). While a successful Arabic novel sells in about 3,000 copies in Egypt with the population of 90 million inhabitants, as many as 75,000 copies of the aforementioned book Taxi were snapped up (Haeri 2009: 424; Taxi 2017). It means that switching from standard Arabic to the vernacular for writing novels could potentially increase the consumption of Arabic-language fiction over twenty-fold in the Arabic-speaking states. But neither writers nor publishers subscribe to this idea (Mlynxqualey 2010). It could easily lead to a religiously underpinned political backlash, violence, and riots, similar to those in 1901 in Athens when the Gospel of St Matthew was published in Demotic. The Arab world's narrow highly educated and affluent class would not risk it. Only members of this class received enough schooling to master standard Arabic to such a high level that they are able to derive pleasure from the perusal of belles-lettres. This option is not available to the less-educated and poorer masses. Hence, reading Arabic novels as a popular pastime does not exist in the Arab countries. It is an elitist activity (Khidayer 2017; Morrow 2016: 65-64; Qualey 2017).

For the poor and uneducated masses, the only possibility to acquire a vernacular of modernity which is both a language of books and popular television is through immersion in a speech community of such a language. Obviously, in the face of the pronounced absence of any standard Arabic speech community, this language is unable to offer such an option. In the case of the Arabicphone world, the short list of versatile modern languages is limited to English and French, or in other words, it is limited to the languages of the former imperial masters of the numerous erstwhile colonies in Northern Africa and the Middle East. In the westernmost corner of the Maghreb, in Western Sahara at present under Moroccan occupation, the role is also played by Spanish. Poorer Arabs achieve a degree of fluency in French, English, or Spanish by watching western (satellite) television since early childhood, learning a western language at school and most typically by going to Europe or North America for work. Their social betters achieve the same through attending private international schools in which English or French is the language of instruction, and foreign-medium universities either abroad or in the Persian Gulf states. Oftentimes, their parents speak English or French at home apart from an Arabic vernacular (Jaafari 2016).

The best and largest secular-style bookshops can be found in the Egyptian capital of Cairo and in Lebanon, the country being the center of book production in the Arab world since the $19^{\text {th }}$ century. But in such a bookshop, 
Arabic books typically add up to no more than one-fifth of the entire stock on offer (cf Rowell 2016; Soweid 2015). Among them the pride of the place is obviously reserved for lavishly produced copies of the Quran and other religious books, making secular Arabic novels into poor relatives. This is not surprising, given the elevated role of standard Arabic as the holy language of the Quran and Islam. The majority of Arabs do not distinguish between the Classical Arabic of this holy book and the supposedly "secular" Modern Standard Arabic of non-religious publications. However, they notice obvious differences such as ossified usages in Classical Arabic and terms for modern inventions (such as trains or television) in Modern Standard Arabic that do not occur in the Quran, but construe of these two varieties as stylistic registers of the same uniform language of Arabic (cf Blau 1981: 150; Brustad 2015: 21-22; Quranic 2017; Van Mol 2003: 38). Additionally, the heightened symbolic value of the Arabic language prevents writers from tackling subjects and themes, seen by religious authorities as unworthy of expressing with the use of this holy language and its equally sacred script. And if some transgress, the argument of religiously underpinned morality (sharia) allows the powers to silence such voices through censorship and repression. Hence, novels in Arabic rarely transcend social and other boundaries. By remaining within the narrow circle of religiously defined decorum, many Arabic novels may appear rather boring to the western-minded Arabic reader, always in search of novelty and broader horizons (cf Massad 2007: 227-228; Mlynxqualey 2011; Oweidat and Schneider 2009). Recently, the situation started changing, especially in Egypt, Lebanon, and Tunisia, where in the wake of the Arab Spring, some daring fiction has been published on topics ranging from sex to satire to political fiction (Jacquemond 2016: 360-366; Qualey 2015).

To tastes not satisfied by Arabic-language publications, the rest of the stock in a secular Lebanese bookstore caters. Usually, four-fifths of the books on the shelves are in French and English. The restrictions imposed by the religious authorities and Islamic pieties do not extend to publications in western languages. It would be interesting to run a poll in order to establish whether an average educated Arab reads more secular publications in such foreign languages or in Arabic. If the situation remains unchanged, western languages may soon join the constellation of the Arabic diglossia. In this context, the role of the vernacular would remain unchanged, but the use of standard Arabic would be limited to religion, politics, state administration, and formal schooling. On the other hand, French, English, or Spanish would become the "book languages" of the Arab world. Fiction and non-specialist non-fiction would be perused and written in these western "book languages," rather than in standard Arabic. Obviously, the internet may become a game 
changer, over 40 per cent Arabic-speakers now enjoying some access to the web (Arabic Speaking 2017; Haeri 2009: 429).

But as yet, no net movement of any "game-changing" significance emerged, which would encourage writing in vernaculars. Most agree that printed publications should be brought out in standard Arabic, with only one-third and one-fifth of respondents agreeing that Facebook and blogs, respectively, could be written in vernacular (Kindt and Kebede 2017: 29-30). It is interesting to observe the tightly controlled revival of the use of the Amazigh (Berber) language(s), especially in Morocco. However, Arabic speakers do not see Amazigh as part of the Arabic language. On the other hand, this aforementioned revival seems to be tactical, coldly calculated, in the wake of the Arab Spring of 2010-2012, to buy some legitimacy to the Moroccan authorities among the most marginalized sections of society in the country's north. The same is largely true of lukewarm moves to improve the situation of Amazigh speakers in Algeria and Libya (Hoffman 2007: 209; Kumar 2012; Sitou 2015). Till date there is no Amazigh language Wikipedia, which nowadays is the basic yardstick of a language's presence in the cyberspace. The only exception to this continued shunning of vernaculars in the Arab countries is the founding of the vernacular Egyptian Arabic (Masry ${ }^{7}$ ) Wikipedia in 2008. The development of this Masry Wikipedia serendipitously happened to coincide with the Arab Spring. It still grows, despite strong normative criticism that popularly sees Arabic dialects as unworthy of writing; while on the other hand, this view also claims that there can be only one Arabic language (Egyptian Arabic Wikipedia 2017; Panovic 2010; Proposals 2014). The Egyptian Arabic Wikipedia with 17,300 articles under its belt is substantially smaller than the Arabic Wikipedia with over half a million articles. However, the former is still over six times bigger than the Maltese Wikipedia with merely 3,200 articles (List of Wikipedias 2017).

Thus, for better or worse, the emerging triglossia (ternary polyglossia) of standard Arabic, vernaculars, and a western language (Kindt and Kebede 2017: 24) seems to be replicated in the Arab(ic) section of the cyberspace (Miller 2017: 98). The web is constructed and maintained by users who express their views, opinions, and attitudes in this new medium. Thus, their decisions and actions in the cyberspace quite closely reflect the social, political, and economic relations in which they function in the "real" (social, physical, material) world, that is, located outside the internet (Berger 2002; Hambuch 2016).

7 Masry, or more exactly Mașri, means 'Egyptian.' This adjective is derived from the Arabic name of Egypt, or Mișr in standard Arabic and Mașr in Egyptian Arabic (Egyptian Arabic 2017). 


\section{Conclusion: From Chinese to Latin}

The divergence between the vernaculars and standard Arabic is significantly smaller in the Arab world than in China between standard Chinese (Mandarin) and the Chinese dialects. Arab vernaculars are as different from one another as Germanic languages. German and English are different, but not radically so. A certain level of mutually comprehensible communication is possible between German and English speakers, without the need of gaining a command of each other's languages. The same is true of Spanish- and Italianspeakers in the case of Romance languages. On the other hand, some Chinese dialects are radically different from each other, for instance, like German differing from Spanish or Polish from English. No mutually comprehensible verbal communication is possible. However, this serious gap is bridged with the help of the morphemic Chinese script, which maps language at the level of morphemes (simple words). To some extent, speakers of various Chinese dialects can read the same text, but they pronounce it in radically different ways. When read out aloud by speakers of different Chinese dialects, this text becomes incomprehensible to one another, but the written text allows for successful communication at the level of writing (Rovira Esteva 2010: 227239). On the contrary, Arabs use a phonemic script, which is a consonantry (abjad) or a kind of "alphabet" with no letters for representing vowels. Children learn how to read Arabic with the help of special diacritical marks that put in vowels where they should be pronounced (A Textbook 2013; McGuinness 1997: 60). However, the difference between standard Arabic and the vernaculars includes not only vowels but also vocabulary and syntax. Thus, an Arabic vernacular when jotted down in Arabic letters looks as different from standard Arabic on the printed page as in conversation (Hudson 1996: 50).

Unlike Arabic, there is no religion to keep standard Chinese and its dialects together. This role is fulfilled by the three millennia of the continuous tradition of Chinese imperial statehood. It is the longest in the world, and the Chinese script and language are this tradition's foundations. Until the beginning of the $20^{\text {th }}$ century, Classical Chinese was official in China. The situation was similar to that in the Arab world. Classical Chinese was codified at the turn of the third century; hence, it was removed from the vernacular for 17 centuries, that is till the early $20^{\text {th }}$ century. However, between the $14^{\text {th }}$ and $19^{\text {th }}$ centuries, a parallel literacy developed in the vernaculars of various Chinese capitals, before finally settling on the dialect of Beijing. In the Republic of China proclaimed in 1912, the balance started changing in favor of the Beijing vernacular, which was finally promulgated as the country's official language in 1932. Communist China founded in 1949 upheld this decision 
(Liang 2015: 18; Rovira Esteva 2010: 111-115). Obviously, when Classical Chinese was official, Chinese speakers had no speech community to fall back on if they wanted to master this language. But with the promulgation of the Beijing dialect in the role of the Chinese language, such a speech community sprang into life.

The existence of a speech community of China's official language constitutes the main difference between this country and the Arab world in respect of language use. In the $21^{\text {st }}$ century world, Arabic speakers are unique in upholding their official language as a written variety with no speech community. This shows clearly that humans can organize their linguistic arrangements in a myriad of starkly differing ways. None can be identified as the "correct" one to be followed by all. However, the Arab solution tends to be pushing Arabic speakers to embrace a western language as an indispensable addition to the traditional Arabic diglossia of standard Arabic and the vernaculars. Standard Arabic seems to be lacking in giving its users access to certain written aspects of modernity, such as popular fiction. But modernity as practiced in the Arab states may as well dispense with the perusal of fiction as a popular pastime. Modernity without belles-lettres is a clear possibility, perhaps even the dominating norm from the perspective of the entire globe. On the other hand, there is nothing inherent in standard Arabic that prevents it from becoming an everyday vernacular of a speech community, if a decision to this end is taken and followed through with necessary funding and expertise. Likewise, nothing stands in the way of teaching all Arabs standard Arabic to such a degree that they would be able to enjoy fiction written in this distinctly non-vernacular language.

What matters is choices made by Arabs themselves. For time being, however, no one seems to be interested in changing the sociolinguistic status quo as it obtains nowadays across the Arab world. No movement similar to the early $20^{\text {th }}$-century Hebrew-based Zionism aspires to make a somewhat vernacularized and reformed standard Arabic into a language of everyday life with its own speech community. What is more, the majority of the Arab states are not interested in securing necessary outlays on education that would enable teaching all Arabs standard Arabic to such a level of literacy as achieved in the case of vernacular languages in Europe. Obviously, it takes less time, effort, and investment to ensure an appropriately high level of literacy in a vernacular language (be it French, English, or German) than in a nonvernacular language with no speech community to its proverbial "soul."

The Arab world's situation of diglossia appears to be the closest to that which persisted in Western Europe prior to the Reformation and the Counter- 
Reformation in the $16^{\text {th }}$ century. Latin was then the official language of France, Spain, Portugal, or of the plethora of polities in the Apennine Peninsula (or today's Italy). This holy language of the early fifth-century translation of the Catholic Bible retained its elevated role as (almost) the sole written official language in Christian Western Europe for a millennium. In the Romancespeaking area, around the eighth or ninth century, distinct vernaculars began emerging from the late Latin cultural and linguistic commonality, namely, languages now identified as Catalonian, French, Galician, Italian, Portuguese, Romanian, or Spanish. Had Latin been preserved as the holy-cum-official language to this day in Italy, France, Portugal, Romania, or Spain, such a development would have almost perfectly reflected the sociolinguistic situation as it obtains now in the Arab world. We would have spoken of a "Latin world," whose inhabitants - "Latins" - would have spoken the Latin language. Of course, some 12 to 15 centuries after the disappearance of any identifiable Latin speech community, in reality, such hypothetical Latins would have spoken regional vernaculars in everyday life, although they would have written in the Latin of the fifth-century translation of the Catholic Bible. They would have mastered this antique Latin at school and would have written and read publications in it to the exclusion of the entirely oral vernaculars. There would have been no French language, like at present there is no Egyptian language. Well, people would have spoken in French, but would have written only in Latin, thinking that both are one language, namely, Latin.

One may opine that this hypothetical comparison is flawed, because modernity arrived in Western Europe after Latin was decommissioned as the official language. But let us not forget about Central Europe, where Latin persisted in this role until the late $18^{\text {th }}$ century in the Habsburg hereditary lands, and quite uniquely until 1844 in the Kingdom of Hungary, or today's Hungary, Slovakia, northern and western Croatia, northwestern Romania, and westernmost Austria. Modernity - meaning education, technology, medicine, mass book production, newspapers, novels, and popular magazines - entered this region through the medium of Latin (Almási and Subarić 2015). With the rare exception of Romanians, none of the vernaculars used in the Kingdom of Hungary was of a Romance character. The Slavic vernaculars of Croatian, Ruthenian, and Slovak were as different from the German or Hungarian vernaculars as Chinese dialects from one another. From this perspective, the situation was different from what we can observe in the Arab world, namely, all Arabic vernaculars are Semitic and more similar to one another than their Chinese counterparts. 
Full-scale functional modern literacy in Latin was ensured by the complete Latin-medium educational system from elementary schools to universities. The Society of Jesus established this system in Central Europe in the wake of the highly successful Counter-Reformation. It catered to almost all nobles' sons and some richer burghers' sons (Bobková-Valentová 2006). By default, nobles' daughters were excluded from attending school, alongside all peasant children. A total of 2-4 per cent of all children received such Latin-based education, but still a smaller number of them achieved such a high level of literacy that they were able to enjoy reading novels and volumes on technology and travels in this antique language. Nevertheless, quite a few Latin-educated literati continued to compose books in Latin, but simultaneously translated them into vernaculars (mainly German and Hungarian) in order to reach a wider audience and thus generate a bigger profit for their intellectual effort. In this manner, vernaculars were codified into languages and soon eclipsed Latin (Frank-Brandovska 1995: 33-34). The Latin commonality of Central Europe and of the Kingdom of Hungary was irrevocably lost (Hay 1978: 18).

Every change allows for gaining something new and unprecedented, which invariably must be paid for by the loss of an important element of tradition. Dante Alghieri wrote all his "serious books" in Latin, but nowadays he is remembered for his vernacular poetry in the dialect of Florence. This Florentine or Tuscan vernacular became a fully recognized Italian language in the wake of the founding of Italy as an ethnolinguistic nation-state in 1861. In the early $14^{\text {th }}$ century, Dante wrote a small book in Latin, titled De vulgari eloquentia, or "On Eloquence in the Vernacular." He proposed that (Romance) vernaculars should be accorded more dignity as languages of everyday life and that they could be employed for writing poetry. The poet noticed that (Romance) vernaculars were not much different from Latin, but opined that more people would be able to enjoy books written in vernaculars than in Latin (Dante 1996).

On the horizon, there is no Arab poet or authority equal in stature to Dante, who would stand for an Arab vernacular, be it Cairene, Egyptian, Moroccan, or Lebanese (although the trend to write fiction in Egyptian Arabic began in the 1990s and gained a considerable momentum after the Arab Spring [Jacquemond 2016: 358-359]). But language politics in the Arab world does not need to follow the rut travelled in Europe. A triglossia also sounds like a good idea, which the European Union of 24 official languages could also usefully consider. 


\section{Tomasz Kamusella, The Arabic Language: A Latin of Modernity?}

\section{References}

Al-Jabiri, Mohammed Abed. 2009. Democracy, Human Rights and Law in Islamic Thought (Ser: Contemporary Arab Scholarship in the Social Sciences, Vol 1). London: I B Tauris, in association with the Centre for Arab Unity Studies, Beirut, Lebanon.

Al Khamissi, Khaled. 2008. Taxi [translated from the Arabic into English by Jonathan Wright]. Laverstock: Aflame.

Almási, Gábor and Šubarić, Lav, eds. 2015. Latin at the Crossroads of Identity: The Evolution of Linguistic Nationalism in the Kingdom of Hungary (Ser: Central and Eastern Europe, Vol 5). Leiden: Brill.

Amin, Hussein. 1996. Egypt and the Arab World in the Satellite Age (pp 103-126). In: John Sinclair, Elizabeth Jacka, Stuart Cunningham, eds. New Patterns in Global Television: Peripheral Vision. Oxford: Oxford University Press.

Arabic. 2017. Ethnologue: Languages of the World. http://www.ethnologue.com/language/ara. Accessed: Oct 8, 2017.

Arabic Speaking Internet Users Statistics. 2017. www.internetworldstats.com/stats19.htm. Accessed: Jan 31, 2017.

A Textbook to Teach Arabic from the 1950s, Employs Vowel Markers in Every Word to Remove Ambiguity. 2013 [Image]. http://3.bp.blogspot.com/-Al2LGRCAQvA/UQihQXpr9DI/ AAAAAAAAM1I/eQI_5E1EjVU/s1600/Screenshot+-+28-01-2013+\%252C+03_19_13. png. Accessed: May 4, 2017.

Behnstedt, Peter and Woidich, Manfred. 2005. Arabische Dialektgeographie. Eine Einführung (Ser: Handbuch der Orientalistik, Vol 1; Ser: Nahe und Mittlere Osten, Vol 78). Leiden: Brill.

Berger, Anne-Emmanuelle, ed. 2002. Algeria in Others' Languages. Ithaca NY: Cornell University Press.

Blau, Joshua. 1981. The Renaissance of Modern Hebrew and Modern Standard Arabic: Parallels and Differences in the Revival of Two Semitic Languages (Ser: University of California Publications: Near Eastern Studies, Vol 18). Berkeley CA: University of California Press.

Bobkova, Irina. 2012. Message from Ms Irina Bokova, Director-General of UNESCO, on the Occasion of the First World Arabic Language Day 18 December 2012. UNESCO. 18 Dec. www.unesco.org/new/en/unesco/events/prizes-and-celebrations/celebrations/internationaldays/world-arabic-language-day/. Accessed: May 5, 2017.

Bobková-Valentová, Kateřina. 2006. Každodenni život učitele a žáka jezuitského gymnázia. Prague: Karolinum.

Brincat, Joseph M. 2011. Maltese and Other Languages: A Linguistic History of Malta (Ser: Maltese Social Studies, Vol 19). Sta Venera: Midsea Books.

Brustad, Kristen. 2015. The Question of Language (pp 19-35). In: Dwight F Reynolds, ed. The Cambridge Companion to Modern Arab Culture. Cambridge: Cambridge University Press.

Cadei, Emily. 2015. Many Women In The Arab World Are Highly Educated, But Underemployed. Huffpost: The World Post. 13 May. http://www.huffingtonpost. com/2015/05/13/arab-world-women-education_n_7277296.html. Accessed: Oct 7, 2017. 


\section{Journal of Nationalism, Memory \& Language Politics 11(2)}

Choueiri, Youssef M. 2005. Arab Nationalism: A History Nation and State in the Arab World. Oxford: Blackwell.

Danecki, Janusz. 2000. Wspótczesny język arabski i jego dialekty (Ser: Języki Azji i Afryki). Warsaw: Wydawnictwo Akademickie Dialog.

Danişmend, İsmail Hami. 1935. Türkçe-osmanlica-fransizca sözlük / Dictionnaire turcottoman-français. Istanbul: Kanaat Kütüphanesi

Dante Alighieri. 1996. De vulgari eloquentia (edited and translated by Steven Botterill). Cambridge: Cambridge University Press.

Doss, Madiha and Davies, Humphrey 2013. al-ÁAmmiyya al-mișriyya al-maktūba: mukhtārāt min 1401 ilā 2009. Cairo: al-Hay'a al-mișriyya al-āmma li-l-kitāb.

Education Enrolment Trends of Women in the Middle East. 2014. ICEF Monitor. 8 Jul. http:// monitor.icef.com/2014/07/increasing-participation-by-women-in-middle-east-education/. Accessed: Oct 7, 2017.

Egyptian Arabic. 2017. Wikipedia. http://en.wikipedia.org/wiki/Egyptian_Arabic. Accessed: Oct 8, 2017.

Egyptian Arabic Wikipedia. 2017. Wikipedia. http://en.wikipedia.org/wiki/Egyptian_ Arabic_Wikipedia. Accessed: Oct 7, 2017.

Farah, Tawfic E, ed. 1987. Pan-Arabism and Arab Nationalism: The Continuing Debate. Boulder CO: Westview.

Ferguson, Charles A. 1959. Diglossia (pp 325-340). Word. Vol 15, No 2.

Frank-Barandovska, Vera. 1995. Latina jako mezinárodni jazyk. Dobřichovice: Akademia libroservo and Kava-Pech.

Haeri, Niloofar. 2003. Sacred Language, Ordinary People: Dilemmas of Culture and Politics in Egypt: Religion, State and Modernity in Egypt. New York: Palgrave Macmillan.

Haeri, Niloofar. 2009. The Elephant in the Room: Language and Literacy in the Arab World (pp 418-430). In: David R Olson and Nancy Torrance, eds. The Cambridge Handbook of Literacy. Cambridge: Cambridge University Press.

Hambuch, Doris. 2016. The Pleasures of Polyglossia in Emirati Cinema: Focus on 'From A to B' and 'Abdullah' (pp 49-61). Horizons in Humanities and Social Sciences: An International Refereed Journal. Vol 2, No 1. http://www.researchgate.net/publication/308200966_ The_Pleasures_of_Polyglossia_in_Emirati_Cinema_Focus_on_'From_A_to_B' and_Abdullah'. Accessed: May 5, 2017.

Hammoud, Rafika. 2000. Non-Formal Education for Girls. Beirut: UNESCO.

Hay, Dens. 1978. Fiat Lux (pp 5-25). In: Paul A. Winckler, ed. Reader in the History of Books and Printing (Ser: Readers in Librarianship and Information Science, Vol 26). Englewood CO: Information Handling Services.

Hoffman, Katherine E. 2007. We Share Walls: Language, Land, and Gender in Berber Morocco. Malden MA: Blackwell Publishing.

Hudson, R A. 1996. Sociolinguistics (Ser: Cambridge Textbooks in Linguistics). Cambridge: Cambridge University Press.

Huebler, Friedrich and Lu, Weixin. 2013. Adult and Youth Literacy: National, Regional and Global Trends, 1985-2015. Montreal: UNESCO Institute for Statistics. 
Jaafari, Shirin. 2016. 'I'm Arab but I Don't Speak Arabic.' PRI. 14 Nov. http://www.pri.org/ stories/2016-11-14/im-arab-i-dont-speak-arabic. Accessed: May 5, 2017.

Jacquemond, Richard. 2016. Satiric Literature and Other "Popular" Literary Genres in Egypt Today (pp 349-367). Journal of Arabic and Islamic Studies. Vol 16. www.hf.uio.no/ikos/ forskning/publikasjoner/tidsskrifter/jais/volume/vol16/. Accessed: Oct 8, 2017.

Jankowski, Henryk. 2010. Język krymskotatarski (Ser: Języki Azji i Afryki). Warsaw: Wydawnictwo Akademickie Dialog.

Khidayer, Emíre. 2017. Arábia chutí. týždeň. 8 Jan. http://www.tyzden.sk/reportaze/36468/ arabia-chuti/. Accessed: Oct 8, 2017.

Kindt, Kristian Takvam and Kebede, Tewodros Aragie. 2017. A Language for the People? Quantitative Indicators of Written dārija and 'àmmiyya in Cairo and Rabat (pp 18-40). In: Jacob Høigilt and Gunvor Mejdell, eds. The Politics of Written Language in the Arab World: Writing Change (Ser: Studies in Semitic Languages and Linguistics). Leiden: Brill.

Kościelniak, Krzysztof. 2004. Grecy i Arabowie. Historia Kościota melkickiego (katolickiego) na ziemiach zdobytych przez muzutmanów (634-1516). Cracow: Wydawnictwo Unum.

Kumar, Vikas. 2012. The Future of Berber Languages After the Arab Spring. AtlanticCommunity. 14 Jun. www.atlantic-community.org/index.php/Open_Think_Tank_Article/ The_Future_of_Berber_Languages_After_the_Arab_Spring. Accessed: Oct 7, 2017.

Lane, Jan-Erik and Redissi, Hamadi. 2009. Religion and Politics: Islam and Muslim Civilization. Farnham Surrey: Ashgate.

Lewis, Bernard. 1988. The Political Language of Islam. Chicago IL: University of Chicago Press.

Liang, Sihua. 2015. Language Attitudes and Identities in Multilingual China: A Linguistic Ethnography. Heidelberg: Springer.

List of Countries where Arabic is an Official Language. 2017. Wikipedia. http://en.wikipedia. org/wiki/List_of_countries_where_Arabic_is_an_official_language. Accessed: May 5, 2017.

List of Wikipedias by Language Group: Semitic. 2017. Wikimedia: Meat-Wiki. http://meta. wikimedia.org/wiki/List_of_Wikipedias_by_language_group\#Semitic_.28790.2C085_ Articles.2C_13.2C906_Active_Users.29. Accessed: Oct 7, 2017.

Literacy and Adult Education in the Arab World. 2003. Beirut: UNESCO, Regional Office for Education in the Arab States and Hamburg: UNESCO Institute for Education. www. unesco.org/education/uie/pdf/country/arab_world.pdf. Accessed: Jan 30, 2017.

McGuinness, Diane. 1997. Why Our Children Can't Read, and What We Can Do About It: A Scientific Revolution in Reading. New York: The Free Press, a divsion of Simon \& Schuster.

Majda, Tadeusz. 2001. Język turecki (Ser: Języki Azji i Afryki). Warsaw: Wydawnictwo Akademickie Dialog.

Malik, Maszlee. 2017. Foundations of Islamic Governance: A Southeast Asian Perspective (Ser: Routledge Studies on Islam and Muslims in Southeast Asia). London: Routledge.

Massad, Joseph A. 2007. Desiring Arabs. Chicago: University of Chicago Press.

Mejdell, Gunvor. 2006. Mixed Styles in Spoken Arabic in Egypt: Somewhere Between Order and Chaos (Ser: Studies in Semitic Languages and Linguistics, Vol 48). Leiden: Brill. 


\section{Journal of Nationalism, Memory \& Language Politics 11(2)}

Member States of the Arab League. 2017. Wikipedia. http://en.wikipedia.org/wiki/Member_ states_of_the_Arab_League. Accessed: Oct 8, 2017.

Miller, Catherine. 2017. Contemporary Dārija Writings in Morocco: Ideology and Practices (pp 90-115). In: Jacob Høigilt and Gunvor Mejdell, eds. The Politics of Written Language in the Arab World: Writing Change (Ser: Studies in Semitic Languages and Linguistics). Leiden: Brill.

Mlynxqualey. 2010. P.S.: Is Colloquial Arabic Destroying the (Literary) World? Or Is It the Internet? Arabic Literature (in English). 24 Apr. http://arablit.org/2010/04/24/p-s-iscolloquial-arabic-destroying-the-literary-world/. Accessed: May 5, 2017.

Mlynxqualey. 2011. Religion and Fiction in Egypt: (Self) Censorship is Part of the Problem. Arabic Literature (in English). 3 Jan. https://arablit.org/2011/01/03/religion-and-fiction-inegypt-self-censorship-is-part-of-the-problem/. Accessed: May 5, 2017.

Mommsen, Wolfgang. 1987. Personal Conduct and Societal Change (pp 35-51). In: Scott lash and Sam Whimster, eds. Max Weber, Rationality and Modernity. London: Routledge.

Morrow, John Andrew. 2016. Restoring the Balance: Using the Qur'an and the Sunnah to Guide a Return to the Prophet's Islam. Newcastle Upon Tyne: Cambridge Scholars Publishing.

Oweidat, Nadia and Schneider, Cynthia P. 2009. The Great Silencing: Intolerance and Censorship in the Arab World. Brookings. 13 Oct. http://www.brookings.edu/opinions/ the-great-silencing-intolerance-and-censorship-in-the-arab-world/. Accessed: Oct 7, 2017.

Panovic, Ivan. 2010. The Beginnings of Wikipedia Masry (pp 93-127). Al-Logha: Series of Papers in Linguistics. Vol 10, No 8, Jun. http://dr.ntu.edu.sg/handle/10220/42227. Accessed: Oct 8, 2017.

Proposals for Closing Projects/Deletion of Wikipedia Masri (Egyptian Arabic Dialect). 2014. Wikimedia: Meat Wiki. http://meta.wikimedia.org/wiki/Proposals_for_closing_projects/ Deletion_of_Wikipedia_Masri_(Egyptian_Arabic_Dialect). Accessed: Oct 7, 2017.

Qualey, Marcia Lynx. 2015. Tunisian Novel Wins 'Arabic Booker' in Abu Dhabi Despite UAE Ban. The Guardian. 6 May. http://www.theguardian.com/books/2015/may/06/ tunisian-novel-wins-arabic-booker-in-abu-dhabi-despite-uae-ban. Accessed: Oct 8, 2017.

Qualey, Marcia Lynx. 2017. Colloquialising Arabic Literature. http://www.mashallahnews. com/language/colloquialising-arabic-literature.html. Accessed: May 5, 2017.

Quranic Arabic vs. Modern Standard Arabic. 2017. Cairo: Arab Academy. http://www. arabacademy.com/quranic-arabic-vs-modern-standard-arabic/. Accessed: Oct 7, 2017.

Rosenbaum, Gabriel M. 2011. The Rise and Expansion of Colloquial Egyptian Arabic as a Literary Language (pp 323-343). In: Rakefet Sela-Sheffy and Gideon Toury, eds. Culture Contacts and the Making of Cultures: Papers in Homage to Itamar Even-Zohar. Tel-Aviv: Unit of Culture Research, Tel Aviv University.

Rosner, Mike and Joachimsen, Jan. 2012. The Maltese Language in the Digital Age / Il-Lingwa Maltija Fl-Era Di®itali (Ser: White Paper Series / Serje ta' White Papers). Berlin: Springers.

Rovira Esteva, Sara. 2010. Lengua y escritura chinas. Mitos y realidades (Ser: Biblioteca de China contemporánea, Vol 21). Barcelona: Bellaterra.

Rowell, Axel. 2016. The Best Bookshops in Beirut, Lebanon. Review of Books. 20 May. blogs. lse.ac.uk/lsereviewofbooks/2016/05/20/the-best-bookshops-in-beirut-lebanon/. Accessed: Jan 31, 2017. 


\section{Tomasz Kamusella, The Arabic Language: A Latin of Modernity?}

Sitou, Imad. 2015. Morocco's Amazighs Still Feel Marginalized. Al-Monitor. 18 May. www. al-monitor.com/pulse/originals/2015/05/Morocco-language-Amazigh-constitutioneducation.html. Accessed: Oct 7, 2017.

Soweid, Loulwa. 2015. Between the Shelves, Hamra's Little Bookshop Stands Tall Among Giants. Beirut. 12 Jan. www.beirut.com/1/38061. Accessed: Jan 31, 2017.

Stacy, R H. 1974. Russian Literary Criticism: A Short History. Syracuse NY: Syracuse University Press.

Subgroups: Arabic. 2017. Ethnologue: Languages of the World. http://www.ethnologue.com/ subgroups/arabic. Accessed: Oct 8, 2017.

Suleiman, Yasir. 2003. The Arabic Language and National Identity: A Study in Ideology. Washington DC: Georgetown University Press.

Tageldin, Shaden M. 2011. Disarming Words: Empire and the Seductions of Translation in Egypt (Ser: Flashpoints, Vol 5). Berkeley CA: University of California Press.

Taxi (Book). 2017. Wikipedia. http://en.wikipedia.org/wiki/Taxi_(book). Accessed: Jan 31, 2017.

Update \& Request for ISO 639 Lang Candidates. 2000. Linguist. 22 Feb. http://xml. coverpages.org/ClewsLinguistList200002.html. Accessed: Oct 8, 2017.

Van Mol, Mark. 2003. Variation in Modern Standard Arabic in Radio News Broadcasts: A Synchronic Descriptive Investigation into the Use of Complementary Particles (Ser: Orientalia Lovaniensia Analecta, Vol 117). Leuven: Uitgeverij Peeters and Department Oosterse Studies.

Versteegh, Kees. 2014. The Arabic Language. Edinburgh: Edinburgh University Press

Zajączkowski, Włodzimierz. 1966. Język i folklor Gagauzów z Bułgarii (Ser: Prace Komisji Orientalistycznej - Polska Akademia Nauk, Oddział w Krakowie, Vol 5). Cracow: Państwowe Wydawnictwo Naukowe.

Zajączkowski, Włodzimierz. 1975. Język i folklor Tatarów z Dobrudży rumuńskiej. Cracow: Zakład Narodowy im. Ossolińskich. 